\title{
Faktor-Faktor Yang Mempengaruhi Kejadian Phlebitis Di RSUD Encik Mariyam Tahun 2020
}

\author{
Amrullah $^{1}$, Sri Muharni ${ }^{2}$, Utari Christya Wardhani ${ }^{3}$ \\ Program Studi Ilmu Keperawatan STIKes Awal Bros Batam \\ Jl. Abulyatama Kelurahan Belian Kecamatan Batam Kota \\ Email korespondensi: amr.tyr86@gmail.com
}

\begin{abstract}
ABSTRAK
Pencegahan dan pengendalian infeksi merupakan bagian dari sasaran keselamatan pasien, mencakup infeksi aliran darah primer (IADP) dengan manifestasi salah satunya yaitu phlebitis. Phlebitis yaitu suatu peradangan pada vena yang mengalami trauma beberapa faktor yang diketahui berhubungan dengan kejadian phlebitis adalah faktor kimia, faktor mekanis, dan faktor bakterial. Tujuan penelitian ini adalah mengetahui faktor-faktor yang berhubungan dengan kejadian phlebitis di RSUD Encik Mariyam tahun 2020. Rancangan penelitian yang digunakan adalah Analitic-observational dengan pendekatan cross-sectional. Metode sampling yang digunakan adalah purpossive sampling dengan besar sample 39 orang pasien yang mendapat terapi Intravena di RSUD Encik Mariyam. Data penelitian dikumpulkan melalui metode observasi oleh peneliti dan data sekunder berupa rekam medis pasien. Data hasil penelitian dianalisa secara univariat dengan tabel frekuensi dan uji bivariat dengan uji Spearman Rho. Hasil analisa univariat didapatkan gambaran cairan intravena yang digunakan mayoritas cairan isotonis (71.8\%); lokasi insersi kanul intravena pada vena metacarpal (66.7\%); gambaran lama terpasang kanul intravena $<72$ jam (69.2\%); gambaran perawatan balutan intravena yang tidak dilakukan (61.5\%); dan gambaran kejadian phlebitis yaitu tidak phlebitis (82.1\%). Hasil analisa bivariat didapatkan $p$ value $=0.000$ pada hubungan jenis cairan intravena dengan kejadian phlebitis; $p$ value $=0.040$ pada hubungan lokasi insersi kanul intravena dengan kejadian phlebitis; $p$ value $=0.000$ pada hubungan lama terpasang kanul intravena dengan kejadian phlebitis; dan $p$ value $=$ 0.021 pada hubungan perawatan balutan kanul intravena dengan kejadian phlebitis. Sehingga dapat disimpulkan ada hubungan yang signifikan antara jenis cairan intravena, lokasi insersi kanul intravena, lama terpasang kanul intravena dan perawatan balutan initravena dengan kejadian phlebitis di RSUD Encik Mariyam tahun 2020. Diharapkan hasil penelitian ini dapat dijadikan bahan pertimbangan terkait penyusunan dan pelaksanaan SOP pemasangan dan perawatan infus, serta pertimbangan dalam surveillance Komite PPI terkait kejadian Infeksi Aliran Darah Primer (IADP).
\end{abstract}

Kata kunci: Phlebitis; intravena; infus 


\title{
Factors Related To Phlebitis Incidents In Encik Mariyam State Hospital, 2020
}

\begin{abstract}
Infection Prevention and Control is part of the patient's safety objectives, which include the primary blood flow infection with phlebitis as one of the manifestations. Phlebitis is an inflammation of the veins due to a trauma to the veins. Several factors are known to relate to the incidence of phlebitides, such as the chemical factor, mechanical factor, and bacterial factors. This research aims to explore the aspects related to the incidence of phlebitis in Encik Mariyam State Hospital year 2020. This study used an analytic-observational design and a cross-sectional time approach. This study's sampling method is purposive sampling, resulting in 39 number of samples from the total patients who received Intravenous therapy in Encik Mariyam state hospital. Data research is collected through observation by the researcher and collecting secondary data from the patients' medical records. Each of the data variables was analyzed and displayed in a frequency table and the bivariate test with the Spearman Rho test. The isotonic intravenous fluid (71.8 percent) is a description of the most used intravenous fluids; $t$ he location of cannula insertion is at the metacarpal veins (66.7 percent); intravenous cannula dur ation < 72 hours (69.2 percent); unchanged intravenous dressing (61.5 percent); and no incidence of phlebitis (82.1 percent). Bivariate analysis results obtained p-value $=0.000$ in the relationship between types of intravenous fluids with the incidence of phlebitis; $p$-value $=0.040$ in the relationship between the location of intravenous cannula insertion and the incidence of phlebitis; $p$-value $=0,000$ in the relationship between the duration of intravenous cannula and the incidence of phlebitis; and p-value $=0.021$ on the relationship between intravenous cannula dressing treatment with the incidence of phlebitis. So it can be concluded there is a significant relationship between types of intravenous fluids, the insertion location of the cannula intravenous, duration of the cannula intravenous and care intravenous dressing treatment with the phlebitis incidents in Encik Mariyam State Hospital year 2020. It is expected that the results of this study could be used as some considerations related to the preparation and implementation of the standard procedure of intravenous therapy care, as well as a surveillance consideration for the infection prevention and control committee. Words key: phlebitis; intravenous; infusion
\end{abstract}

Words key : phlebitis; intravenous; infusion

\section{PENDAHULUAN}

Phlebitis didefinisikan sebagai suatu peradangan pada vena yang mengalami trauma, ditegakkan dengan adanya dua atau lebih temuan berupa adanya daerah kemerahan dan hangat disekitar daerah penusukan atau sepanjang vena, nyeri dan rasa lunak didaerah penusukan atau sepanjang vena dan adanya pembengkakan. Phlebitis dapat merugikan pasien jika tidak segera mendapat perhatian. Pada fase awal phlebitis umumnya dapat diatasi dengan menghentikan terapi intravena dan mengaplikasikan kompres hangat pada area yang bengkak dan merah. Komplikasi lain yang mungkin terjadi akibat pemberian terapi intravena antara lain infeksi, thrombosis, tromboplebitis superfisial, dan tromboplebitis sepsis yang merupakan komplikasi paling serius yang ditandai dengan adanya thrombosis vena dan reaksi inflamasi akibat invasi bakteri (Higginson dan Parry, 2016).

Banyak faktor telah dianggap terlibat dalam pathogenesis phlebitis, antara lain, faktor kimia, faktor mekanis, dan faktor bakterial. Faktor-faktor kimia seperti obat atau cairan intravena yang bersifat iritan terhadap dinding vena. Faktor kimiawi terkait jenis cairan intravena merupakan penyebab phlebitis yang paling sering. Hal ini 
berkaitan dengan sifat larutan hipertonis, yaitu larutan dengan osmolalitas yang lebih tinggi dari cairan ekstraseluler (CES), apabila masuk ke sistem sirkulasi akan menarik air dari kompartemen intraselular ke intravascular dan mengakibatkan sel-sel pada pembuluh darah dan sel-sel darah mengkerut dan rusak yang kemudian memicu respon inflamasi (Smeltzer \& Bare, 2016).

Faktor mekanis mencakup bahan, ukuran kateter, lokasi dan lama kanulasi serta ageninfeksius. Pembuluh darah mengalami trauma akibat kontak fisik dengan kanula intravena. Kanul yang berukuran besar jika digunakan pada vena yang berlumen kecil dapat mengiritasi bagian intima dari vena, oleh karena itu penting untuk mempertimbangkan ukuran kateter intravena untuk mencegah terjadinya phlebitis. Disamping itu fiksasi yang kurang tepat dapat pula menyebabkan inflamasi yang memicu phlebitis. Phlebitis yang disebabkan karena lokasi pemasangan terapi intravena bisa diminimalisirkan dengan menggunakan vena yang lokasinya jauh dari pergelangan tangan/persendian, untuk mengurangi pergerakan kanula di dalam pembuluh darah (Saefulmilah, 2016).

Teknik aseptik dressing yang tidak baik dari petugas medis merupakan salah satu faktor yang menyebabkan terjadinya phlebitis bakterial. Plebitis bisa disebabkan karena adanya kontaminasi mikroba melalui titik akses ke sirkulasi dalam periode tertentu. Penggantian balutan yang jarang dan tidak teratur mengakibatkan kurangnya observasi pada lokasi pemasangan infus dan meningkatkan resiko phlebitis (Atika, 2017).

Hasil studi pendahuluan pada tanggal 08 Oktober 2019 di Komite PPI RSUD Encik Mariyam, didapatkan data kejadian phlebitis pada pasien dewasa dari Januari sampai dengan September tahun 2019 yaitu sebanyak $10,39 \%$. Jumlah ini lebih tinggi dari standar yang direkomendasikan oleh INS (Infusion Nurse Society) yaitu 5\% (Salgueiro, 2017). Hasi wawancara yang dilakukan pada 3 orang perawat di ruangan rawat inap didapatkan data penyebab phlebitis yang sering ditemui adalah lama terpasang infus lebih dari 3 hari, pergerakan aktif pada area pemasangan infus dan pemberian obat-obatan injeksi terutama antibiotik injeksi. Hal inilah yang menarik minat peneliti untuk meneliti faktor-faktor yang berhubungan dengan kejadian phlebitis di RSUD Encik Mariyam.

\section{METODE PENELITIAN}

Rancang penelitian ini menggunakan desain Analitic-observational dengan pendekatan cross- sectional. Tekhnik sampling yang digunakan adalah purposive sampling dengan besar sampel yang digunakan sebanyak 39 responden yang merupakan pasien rawat inap dewasa. Pengumpulan data dilakukan dengan observasi dan studi data rekam medis pasien. Hasil penelitian dianalisa dengan uji Spearman rho dengan nilai kemaknaan $0.05 \%$. 


\section{HASIL DAN PEMBAHASAN}

\section{Analisa Univariat}

Tabel 1

Distribusi frekuensi karakteristik responden, jenis cairan, lokasi insersi, durasi terpasang, perawatan balutan, kejadian phlebitis $(n=39)$

\begin{tabular}{|c|c|c|c|}
\hline No & Karakteristik & $\mathrm{f}$ & $\%$ \\
\hline \multirow[t]{3}{*}{1} & Jenis kelamin & & \\
\hline & Laki-laki & 10 & 25.6 \\
\hline & Perempuan & 29 & 74.4 \\
\hline \multirow[t]{4}{*}{2} & Umur & & \\
\hline & $<25$ tahun & 4 & 10.3 \\
\hline & $25-50$ tahun & 21 & 53.8 \\
\hline & $>50$ tahun & 14 & 35.9 \\
\hline \multirow[t]{3}{*}{3} & Cairan intravena & & \\
\hline & Isotonis & 28 & 71.8 \\
\hline & Hipertonis & 11 & 28.2 \\
\hline \multirow[t]{3}{*}{4} & Insersi kanul intravena & & \\
\hline & Vena cefalica & 13 & 33.3 \\
\hline & Vena metacarpal & 26 & 66.7 \\
\hline \multirow[t]{3}{*}{5} & Durasi terpasang kanul intravena & & \\
\hline & $<72$ jam & 27 & 69.2 \\
\hline & $>72$ jam & 12 & 30.8 \\
\hline \multirow[t]{3}{*}{6} & Perawatan balutan intravena & & \\
\hline & Dilakukan & 15 & 38.5 \\
\hline & Tidak dilakukan & 24 & 61.5 \\
\hline \multirow[t]{3}{*}{7} & Kejadian phlebitis & & \\
\hline & Tidak phlebitis & 32 & 82.1 \\
\hline & Phlebitis & 7 & 17.9 \\
\hline
\end{tabular}

Berdasarkan tabel 1 diatas diketahui mayoritas responden adalah perempuan $(74.4 \%)$ dan lebih dari setengahnya berusia antara $25-50$ tahun $(53.8 \%)$; mayoritas cairan yang digunakan adalah cairan isotonis $(71.8 \%)$; lebih dari setengah insersi kanul intravena dilakukan pada vena metacarpal (66.7\%); lebih dari setengah kanul intravena dipertahankan selama $<72$ jam (69.2\%); lebih dari setengah responden tidak mendapat perawatan balutan intravena $(61.5 \%)$; dan mayoritas responden tidak mengalami phlebitis $(82.1 \%)$.

\section{Analisa Bivariat}

a. Tabel silang lokasi insersi kanul intravena dan kejadian phelebitis 
Tabel 2

Tabel silang lokasi insersi kanul intravena dan kejadian plebitis

\begin{tabular}{crrr}
\hline \multirow{2}{*}{ Lokasi insersi intravena } & \multicolumn{2}{c}{ Kejadian plebitis } & \multicolumn{2}{l}{ Total } \\
\cline { 2 - 4 } Vidak Phlebitis & Phlebitis & 13 \\
Vena cephalica & 13 & 0 & $33.3 \%$ \\
\multirow{2}{*}{ Vena metacarpal } & $33.3 \%$ & $0.0 \%$ & 26 \\
& 19 & 7 & $66.6 \%$ \\
\hline \multirow{2}{*}{ Total } & $48.7 \%$ & $17.9 \%$ & 39 \\
& 32 & $17.9 \%$ & $100.0 \%$ \\
\hline
\end{tabular}

Pada tabel 2 diatas dapat diketahui tabel silang vena cephalica dan tidak phlebitis sebesar $33.3 \%$, tidak terdapat kejadian phlebitis pada pemasangan vena di vena cephalica; tabel silang vena metacarpal dan tidak phlebitis sebesar 48.7\%; serta vena metacarpal dan phlebitis sebesar 17.9\%. Hasil uji Spearman Rho didapatkan $\mathrm{p}$ value $=0.040$ dan $\mathrm{r}=$ 0.331 yang bermakna korelasi lemah.

Pada pemasangan canul intravena pemilihan vena harus diperhatikan dengan baik. Diantaranya dalah vena yang besar, vena yang diperifer terlebih dulu, vena yang tidak bercabang, dan vena yang terletak tidak didekat persendian. Lokasi vena perifer yang sering digunakan pada pemasangan infus adalah vena supervisial atau perifer kutan terletak di dalam fasia subcutan dan merupakan akses paling mudah untuk terapi intravena. Daerah tempat infus yang memungkinkan adalah permukaan dorsal tangan (vena supervisial dorsalis, vena basalika, vena sefalika), lengan bagian dalam (vena basalika, vena sefalika, vena kubital median dan vena median lengan bawah.
Hasil penelitian ini sejalan dengan hasil penelitian terkait lokasi insersi kanul intravena lainnya, penelitian tentang Study on incidence of phlebitis following the use of pherpheral intravenous catheter didapatkan data hubungan lokasi insersi kanul intravena dengan kejadian plebitis (OR 1.27; IC95 0.05-0.30, p < 0.05) (Mandal, 2019).

Pemilihan lokasi insersi kanul intravena pada penelitian ini diutamakan pada vena metacarpal terlebih dahulu berdasarkan asas penggunaan vena distal dalam manipulasi pembuluh darah. Namun apabila vena metacarpal tidak memungkinkan untuk dilakukan insersi kanul intravena (kecil, bercabang, kolaps dan sebagainya) atau pada pasien lansia dengan pembuluh darah yang rawan pecah, insersi kanul intravena dilakukan di vena cephalika.

Vena metacarpal lebih kecil dan distal dibandingkan dengan vena cephalica. Sehubungan dengan hal ini penggunaan kanul intravena ukuran besar (diatas 20G) tidak disarankan pada vena kecil seperti pada vena metacarpal karena kanul yang diinsersikan akan selalu bergesekan dengan dinding vena 
yang dapat memicu trauma. Selain itu karena posisi vena metacarpal yang lebih distal, aliran darah pada vena metacarpal akan lebih lambat dari pada vena cephalica. Hal ini perlu diperhatikan ketika memberikan infus dengan kecepatan tinggi, hiper/hipotonis atau darah dan produk darah, aliran darah yang lebih lambat pada vena metacarpal mengakibatkan cairan yang diinfuskan bertahan lebih lama di sekitaran area infus yang dapat memicu peradangan vena.

b. Tabel silang cairan intravena dan kejadian plebitis

Tabel 3

Tabel silang cairan intravena dan kejadian plebitis

\begin{tabular}{|c|c|c|c|}
\hline \multirow{2}{*}{ Jenis cairan intravena } & \multicolumn{2}{|c|}{ Kejadian plebitis } & \multirow{2}{*}{ Total } \\
\hline & Tidak Phlebitis & Phlebitis & \\
\hline \multirow[b]{2}{*}{ Isotonis } & 27 & 1 & 28 \\
\hline & $69.2 \%$ & $2.6 \%$ & $71.8 \%$ \\
\hline \multirow{2}{*}{ Hipertonis } & 5 & 6 & 7 \\
\hline & $12.8 \%$ & $15.4 \%$ & $28.2 \%$ \\
\hline \multirow{2}{*}{ Total } & 32 & 7 & 39 \\
\hline & $82.1 \%$ & $17.9 \%$ & $100.0 \%$ \\
\hline
\end{tabular}

Pada tabel 3 diatas dapat diketahui tabel silang cairan isotonis dan tidak phlebitis sebesar $69.2 \%$, cairan isotonis dan phlebitis sebesar 2.6\%; tabel silang cairan hipertonis dan tidak phlebitis sebesar 12.8\%; serta cairan hipertonis dan phlebitis sebesar 15.4\%. Hasil uji Spearman Rho didapatkan $\mathrm{p}$ value $=0.000$ dan $\mathrm{r}=$ 0.598 yang bermakna korelasi sedang.

Hasil analisa proporsi antara jenis cairan intravena dan kejadian phlebitis menunjukkan gambaran peningkatan jumlah kejadian phlebitis pada pasien yang mendapat terapi intravena yang hipertonis dijelaskan oleh teori sifat iritan larutan hipertonis pada tunika intima pembuluh darah vena, terutama apabila diinfuskan melalui vena yang kecil dan dengan kecepatan yang tinggi.
Beberapa penelitian terdahulu sudah membuktikan teori multikausa phlebitis, dimana kejadian phlebitis bisa disebabkan satu atau lebih faktor secara bersamaan (overlapping). Hasil penelitian Teresa (2017) tentang Infectious or noninfectious phlebitis: lessons from a an interventional programm on phlebitis associated to peripheral venous catheter dapat disimpulkan kejadian phlebitis tanpa infeksi berhubungan dengan komponen yang bersifat iritan (OR 6.1; IC95 1.3-29, $\mathrm{p}<0.05)$.

Pada hasil penelitian ini kejadian phlebitis ditemukan dialami oleh responden baik yang mendapat cairan intravena yang bersifat isotonis maupun hipertonis, meskipun dengan angka kejadian yang jauh berbeda. Dari hasil pengamatan adanya kesenjangan antara teori dan kenyataan ini 
dapat berhubungan dengan beberapa faktor perancu yang tidak dapat dikontrol sepenuhnya seperti diagnosis, tingkat mobilitas, serta jenis dan ukuran kanul intravena yang digunakan. Faktor-faktor ini selain faktor yang dijabarkan dalam penelitian ini dapat berkontribusi terkait terjadinya phlebitis pada responden yang mendapat terapi intravena dengan cairan isotonis.

c. Tabel silang durasi terpasang kanul intravena dengan kejadian phlebitis

Tabel 4

Tabel silang lama terpasang kanul intravena dan kejadian phlebitis

\begin{tabular}{|c|c|c|c|}
\hline \multirow{2}{*}{$\begin{array}{c}\text { Lama terpasang kanul } \\
\text { intravena }\end{array}$} & \multicolumn{2}{|c|}{ Kejadian plebitis } & \multirow{2}{*}{ Total } \\
\hline & Tidak Phlebitis & Phlebitis & \\
\hline \multirow{2}{*}{$<72$ jam } & 27 & 0 & 27 \\
\hline & $69.2 \%$ & $0.0 \%$ & $69.2 \%$ \\
\hline \multirow{2}{*}{$>72$ jam } & 5 & 7 & 12 \\
\hline & $12.8 \%$ & $17.9 \%$ & $30.8 \%$ \\
\hline \multirow{2}{*}{ Total } & 32 & 7 & 39 \\
\hline & $82.1 \%$ & $17.9 \%$ & $100.0 \%$ \\
\hline
\end{tabular}

Pada tabel 4 diatas dapat diketahui tabel silang terpasang selama $<72$ jam dan tidak phlebitis sebesar $69.2 \%$, dan tidak terdapat kanul intravena yang terpasang $<72$ jam yang mengalami phlebitis; tabel silang terpasang selama $>72$ jam dan tidak phlebitis sebesar $12.8 \%$; serta terpasang selama $>72$ jam dan phlebitis sebesar $17.9 \%$. Hasil uji Spearman Rho didapatkan $\mathrm{p}$ value $=0.000$ dan $r=0.702$ yang bermakna korelasi kuat.

\section{The Center for Disease Control} and Prevention menganjurkan kateter intravena diganti setiap 7296 jam untuk membatasi potensi infeksi. Batas lama waktunya penggunaan kateter intravena tersebut hanya 72-96 jam. Jika hal tersebut dibiarkan maka akan mempermudah timbulnya peradangan pada pembuluh vena, karena adanya kolonisasi kuman atau bakteri pada daerah penusukan kanula atau pada kepala kanula itu sendiri. Untuk itu sebaiknya kateter intravena diganti tiap 72 jam, meskipun belum ada tanda-tanda plebitis maupun pembekuan pada kanul. Bila timbul tanda-tanda nyeri, kemerahan, pembengkakan dan rasa hangat pada daerah sekitar penusukan kanula intravena maka secepatnya kanul dilepas atau diganti.

Hasil penelitian tentang Phlebitisrelated peripheral venous catheterization and the associated risk factors didapatkan data adanya perbedaan insidensi phlebitis berdasarkan kategori waktu, dengan kejadian tertinggi pada 4972 jam pemasangan $\left(\chi^{2}=64.3, \mathrm{Sd}\right.$ $=3, P<0.05$ ) (Atay, 2018).

Pada hasil penelitian ini seluruh responden dengan kanul intravena yang terpasang $<72$ jam tidak mengalami phlebitis, hal ini medukung teori dan anjuran lama terpasang kanul intravena tidak 
lebih dari 72 jam. Namun terdapat juga responden dengan kanul intravena yang terpasang selama lebih dari 72 jam dan tidak mengalami phlebitis. Hal ini dapat diakitkan dengan faktor-faktor lain seperti yang dibahas dalam penelitian ini dan faktor lainnya seperti faktor kekebalan tubuh/ imunitas responden, dan pemberian obat-obatan injeksi yang dapat bersifat mengiritasi.

d. Tabel silang perawatan balutan kanul intravena dengan kejadian phlebitis

Tabel 5

Tabel silang durasi terpasang kanul intravena dan kejadian plebitis

\begin{tabular}{|c|c|c|c|}
\hline \multirow[b]{2}{*}{ Perawatan balutan } & \multicolumn{2}{|c|}{ Kejadian plebitis } & \multirow[b]{2}{*}{ Total } \\
\hline & Tidak Phlebitis & Phlebitis & \\
\hline \multirow{2}{*}{ Dilakukan } & 15 & 0 & 15 \\
\hline & $38.5 \%$ & $0.0 \%$ & $38.5 \%$ \\
\hline \multirow{2}{*}{ Tidak dilakukan } & 17 & 7 & 26 \\
\hline & $43.6 \%$ & $17.9 \%$ & $61.5 \%$ \\
\hline Total & $\begin{array}{r}32 \\
82.1 \%\end{array}$ & $\begin{array}{r}7 \\
17.9 \%\end{array}$ & $\begin{array}{r}39 \\
100.0 \%\end{array}$ \\
\hline
\end{tabular}

Pada tabel 5 diatas dapat diketahui tabel silang dilakukan perawatan balutan intravena dan tidak phlebitis sebesar $38.5 \%$, dan tidak terdapat balutan kanul intravena yang dilakukan tindakan perawatan balutan mengalami phlebitis; tabel silang tidak dilakukan perawatan balutan intravena dan tidak phlebitis sebesar 43.6\%; serta tidak dilakukan perawatan intravena dan mengalami phlebitis sebesar $17.9 \%$.Hasil uji Spearman Rho didapatkan $\mathrm{p}$ value $=0.021$ dan $\mathrm{r}=0.370$ yang bermakna korelasi lemah.

Perawatan infus bertujuan untuk mempertahankan tehnik steril, mencegah masuknya bakteri ke dalam aliran darah agar tidak terjadi infeksi, dan memantau area insersi kanul intravena sehingga dapat mengurangi kejadian phlebitis. Dressing (perawatan infus) merupakan tindakan yang dilakukan dengan mengganti balutan/ plester pada area insersi. Aseptik dressing adalah perawatan yang dilakukan pada tempat insersi kanul intravena. Frekuensi penggantian balutan ditentukan oleh kondisi kulit klien yang terpasang infus. Dressing dipantau untuk memastikan tetap kering, tertutup dan utuh. Dressing yang utuh berarti pinggir-pinggirnya rapat ke kulit. Jika dressing lembab atau integritasnya tidak baik maka harus segera diganti. Faktor penyebab terjadinya phlebitis adalah frekuensi penggantian balutan yang jarang, mengakibatkan kurangnya observasi pada lokasi pemasangan canul intravena sehingga gejala awal dari phlebitis tidak diketahui.

Penelitian lainnya oleh Büyüky1lmaz (2019) tentang Effectiveness of an Intravenous Protection Device in Pediatric Patients on Catheter Dwell Time and Phlebitis Score didapatkan 
tidak ada perbedaan bermakna terkait penggunaan dressing dan kejadian phlebitis $(p>.05)$. Hal ini dapat berhubungan dengan penerapan perawatan balutan intravena pada seluruh responden dalam penelitian tersebut, selain itu penyebab terjadinya phlebitis pada pasien sebenarnya tidak hanya di karenakan oleh perawatan balutan saja namun bisa juga berasal dari tingkat usia, cairan, penyakit penyerta, status gizi, stress, jenis kelamin, kepatuhan klien dan sebagainya.

Dalam penelitian ini seluruh responden yang mendapat perawatan balutan intravena tidak

\section{SIMPULAN}

1. Lebih dari setengah jumlah responden mendapatkan terapi intravena yang bersifat isotonis.

2. Lebih dari setengah lokasi insersi kanul intravena adalah pada vena metacarpal.

3. Lebih dari setengah kanul intravena terpasang selama $<72$ jam.

4. Lebih dari setengah responden tidak dilakukan perawatan balutan kanul intravena.

5. Mayoritas responden tidak mengalami phlebitis.

6. Ada hubungan jenis cairan intravena dengan kejadian phlebitis di RSUD Encik Mariyam.

7. Ada hubungan lokasi insersi kanul intravena dengan kejadian plebitis di RSUD Encik Mariyam.

8. Ada hubungan durasi terpasang kanul intravena dengan kejadian phlebitis di RSUD Encik Mariyam.

9. Ada hubungan perawatan balutan kanul intravena dengan kejadian mengalami phlebitis, hal ini dapat dihubungkan dengan asumsi perawatan balutan kanul intravena mencegah terbentuknya koloni bakteri pada area insersi kanul intravena sehingga mencegah terjadinya phlebitis. Adanya balutan kanul intravena yang tidak dilakukan perawatan berhubungan tidak adanya indikasi seperti balutan yang basah atau lembab, walaupun balutan tersebut secara kasat mata tampak tidak kotor, ada baiknya tetap dilakukan tindakan perawatan balutan intravena sebagai langkah awal untuk mencegah phlebitis.

phlebitis di RSUD Encik Mariyam.

\section{UCAPAN TERIMAKASIH}

1. Bapak Prof. Dr. Fadil Oenzil, PhD. Sp.GK selaku Ketua STIKes Awal Bros Batam.

2. Ibu Sri Muharni, Ners., M.Kep selaku Ka. Prodi Sarjana Keperawatan STIKes Awal Bros Batam dan pembimbing I.

3. Ibu Utari Christya Wardhani, Ners, M.Kep selaku pembimbing II.

4. Bapak dr. Suryadi selaku direktur RSUD Encik Mariyam.

5. Seluruh Dosen dan staf STIKes Awal Bros Batam.

6. Seluruh Mahasiswa Sarjana Keperawatan Angkatan IX STIKes Awal Bros Batam.

\section{DAFTAR PUSTAKA}

Alexander, et al. 2014. Infusion Nursing: An Evidence-Based Approach $3^{\text {rd }}$ Ed. Missouri: Saunders. 
Anggita, S. 2018. Analisa faktor-faktor terhadap kejadian plebitis pada pasien yang mendapatkan terapi cairan intravena. [online] http://r epo.stikesicmejbg.ac.id/1310/2/ 143210141\%20Sevika\%20Dwi $\% 20$ Anggita\%20Skripsi.pdf. Diakses pada 2 Maret 2020.

Atay, S. Sen, S. Cukurlu, D. 2018. Phlebitis-related peripheral venous catheterization and the associated risk factors. Nigerian Journal of Clinical Practice PG 827-831 vol 21 issue 7 . http://www.njcponline.com/artic le.asp?

Büyükyılmaz, Funda, Şahiner, Nejla C. Cağlar, Seda. Eren, Handan. 2019. Effectiveness of an Intravenous Protection Device in Pediatric Patients on Catheter Dwell Time and Phlebitis Score. Asian Nursing Research,Volume 13, Issue 4, Pages 236-241, ISSN 19761317 https://doi.org/10.1016/j.anr.201 9.09.001.

Dalton, Clayton. 2018. Why Did Sterile Salt Water Become The IV Fluid Of Choice?. [online] http:// https://www.npr.org/sections/he alth-shots/2018/03/31/59766614 $0 /$ why-did-sterile-salt-waterbecome-the-iv-fluid-of-choice. Diakses pada 27 Juni 2020.

Depkes RI. 2015. Panduan Nasional Keselamatan Pasien Rumah Sakit (Patient Safety): Utamakan Keselamatan Pasien. Jakarta: Depkes RI.

Dewantara, A. 2014. Hubungan Lama Pemasangan Infus dengan Kejadian Phlebitis diruang
Bougenville RSUD Embung Fatimah Kota Batam Tahun 2014. Universitas Batam: Batam. Skripsi tidak diterbitkan.

Dorland, N. 2015. Kamus Kedokteran Dorland edisi 31. Jakarta: Penerbit Buku Kedokteran EGC.

Herlina, Meriani, and Anggi G. P. Jafa. "Faktor yang Berhubungan dengan Kejadian Plebitis pada Pasien yang Terpasang Infus di Rumah Sakit Imelda Pekerja Indonesia (RSU Ipi) Medan." Jurnal Ilmiah Keperawatan Imelda, vol. 4, no. 2, 2018, pp. 521-529, doi:10.2411/jikeperaw atan.v4i2.298.

Higginson, R and Parry, A. 2016. Phlebitis: Treatment, Care, and Prevention. Nursing Times. 107 (36). 18-21.

Kim, Young-Ju \& Lee, Sun-Mi \& Park, Ho-Ran \& Sohng, Kyeong-Yae \& Kim, Seok-Jung. 2017. Development of Evidence-based Nursing Practice Guidelines for Peripheral Intravenous Catheter Management in Hospitalized Children and Adult. International Journal of Studies in Nursing. 3. 82. 10.20849/ijsn.v3i1.309.

Kusyati, E., et al. 2016. Keterampilan dan Prosedur Laboratorium Keperawatan Dasar Edisi . EGC : Jakarta

Lestari, D dkk. 2016. Hubungan Jenis Cairan dan Lokasi Pemasangan Infus dengan Kejadian Flebitis pada Pasien Rrawat Inap di RSU Pancaran Kasih GMIM Manado. Ejournal Keperawatan 
(e-Kp) Volume 4 Nomor 1, Mei 2016.

Mandal, A., \& Raghu, K. (2019). Study on incidence of phlebitis following the use of pherpheral intravenous catheter. Journal of family medicine and primary care, 8(9), 2827-2831. https://doi.org/10.4103/jfmpc.jf mpc_559_19

Marseno, R. 2016. Patient Safety. [onli ne]. https://www.scribd.com/do c/266601269/Patient-Safety. Diakses pada 20 Nopember 2019.

Nobre, Alexandra \& Martins, Matilde. 2018. Prevalence of peripheral intravenous catheter-related phlebitis: associated factors. Revista de Enfermagem Referência. IV Série. 127-138. 10.12707/RIV17058.

Nursalam. 2016. Metodologi Penelitian Ilmu Keperawatan: Pendekatan Praktis. Ed. 4. Jakarta: Salemba Medika

Phillips, S., et al (ed). 2014. Venepucture and Cannulation $I^{\text {st }}$ Ed. Oxford, UK: Wiley Publishing.

Pranata, A. 2014. Manajemen Cairan dan Elektrolit. Yogyakarta: Nuha Medika.

Prastika, D. 2015. Kejadian Phlebitis di Rumah Sakit Umum Daerah Majalaya. [online].

Http://jurnal.unpad.ac.id.

Diakses pada 20 Nopember 2019.

Rizky, W. 2016. Analisis Faktor yang Berhubungan dengan Kejadian Phlebitis pada Pasien yang
Terpasang Kateter Intravena di Ruang Bedah Rumah Sakit Ar. Bunda Prabumulih. Jurnal Ners dan Kebidanan Indonesia. 4. 102.

10.21927/jnki.2016.4(2).102108.

Salgueiro-Oliveira, A., et al. 2017. Incidents of Phlebitis in Patients with Peripheral Intravenous Catheters: The Influents of Some Risk Factors.

Saputra, L. 2015. Keterampilan Dasar untuk Perawat dan Bidan. Jakarta: Bina Rupa Aksara.

Saragih, N. 2019. Hubungan antara Lokasi Penusukan Kateter Intravena dengan Kejadian Plebitis Mekanik di Ruang Rawat Inap Cendana RS. USU Medan. http://jurnal.stikessitihajar.ac.id/index.php/jhsphal: 86-90.

Sidabutar, Y. 2015. Hubungan Tonisitas Cairan Intravena dengan Kejadia Phlebitis di Ruang Cendrawasih di Ruang Cendrawasih RSUD Tanjung Uban Tahun 2015. Skripsi Tidak Diterbitkan.

Smeltzer, S dan Bare, B. 2016. Buku Ajar Keperawatan MedikalBedah Brunner \& Suddarth. Alih bahasa: Monica Ester, dkk. Jakarta: EGC.

Sumara, Retno. (2017). Hubungan Lokasi Terapi Intravenus Dengan Kejadian Plebitis. Jurnal Keperawatan Muhammadiyah. 2.10.30651/jk m.v2i1.926.

Sumara, Retno. (2017). Hubungan Lokasi Terapi Intravenus 
Dengan Kejadian Plebitis. Sumijatun. 2014. Standar Keperawatan. Jurnal Keperawatan [online]. Https://slideplayer.inf Muhammadiyah, 2 (1). o/slide/4870656/. Diakses pada $20 \quad$ Nopember 2019. 